\title{
Can your company benefit from German financing?
}

\author{
There are many ways to access German money, but the decision \\ must be based on sound strategy rather than a dire need.
}

\section{Carola Schropp and Jürgen Conrad}

Among European countries, Germany has become the forerunner in offering unique financing options to small biotechnology companies. Generous financing packages are available for US, Canadian, and UK biotechnology companies starting subsidiaries in Germany or entering a joint venture with a German company. Certainly other European countries, such as Denmark and France, have created attractive financing opportunities for biotech companies. But as Helmut Schühsler, one of the leading venture capitalists in Germany, has said, "Germany's financing opportunities cannot be beaten."

The question, then, for many US biotechnology companies, is whether it makes sense to look into offshore financing opportunities. The short answer, according to the consensus opinion at the recent $\mathrm{BIO} \mathrm{CEO} \&$ Investor Conference meeting, is that the startup of a company in Germany has to make strategic sense. The money is a bonus, and should not be the primary reason for starting a company in Europe. "It is not as easy as it is made to look by some of the German officials, who are in the business of attracting biotech companies, make it out to be," says Ralph Christoffersen, CEO of Ribozyme Pharmaceuticals (Boulder, $\mathrm{CO}$-_one of several CEOs to present their experience of starting a company in Germany. "Yet, in the end, it was definitely worth it."

Last July, Ribozyme started Atugen Biotechnology in Berlin, with the goal of applying the company's proprietary ribozyme technology to the area of target validation. Ribozyme had already begun this effort, and in fact, had already signed one deal with a major pharmaceutical company. The company, however, felt that this effort detracted from its main goal of developing novel therapeutics, so it made sense to spin this effort off into a new company. Ribozyme received \$27 million, the largest amount of state subsidies

Carola Schropp is partner at E.B.D. Group, Inc., 6120 Paseo del Norte, Suite J-2, Carslbad, CA 92009 (cschropp@ebdgroup.com) and Jürgen Conrad is president and CEO of ConsulTech GmBH, Nienkemperstrasse 38, 14167 Berlin, Germany (conrad@consultech.de). awarded to a biotech company to date.

Some sources in Germany claim that Ribozyme was lucky to be at the right place at the right time. The company did have a good patent portfolio and its technology fit nicely in the newly founded RNA network in Berlin. The RNA network is a collaboration of universities, institutes, and companies focused on the goal of advancing RNA technologies such as antisense, ribozymes, apatmers, and spiegelmers. The network received about $\$ 44$ million from the German government and the Berlin Senate, and was thus able to contribute to Atugen's financing.

Based on numerous conversations with venture capitalists, government agencies, and banks, we believe that the amount of money received by Atugen was far beyond what most companies can reasonably expect. A more reasonable deal structure is typified by the experience of Exelixis Pharmaceuticals (S. San Francisco, CA). Exelixis owns a minority share of Artemis (Cologne), and together the two companies are developing animal models to test drug candidates for Alzheimer's disease, cancer, and cartilage-related disorders. Artemis's technology is based on the research of Nobel Prize laureates Christiane NüssleinVolhard and Günther Rajweski. With the American company owning less than $25 \%$ of the German company, issues concerning foreign investment were avoided.

\section{Why is this money available?}

The German federal government has identified biotechnology as one of the key industries that will ensure continued prosperity for their country in the next millennium. Attracting US biotechnology companies to start viable, stand-alone companies in Germany is part of the government's strategy to strengthen the industry. The government also hopes to import the management and entrepreneurial talent needed to build these companies. At the moment, biotechnology is hot-so hot that the federal government is making an additional $\$ 2.2$ billion available for research grants earmarked for biotech companies.

In addition, the German government makes money available through its banks, the Technologiebeteiligungsgesellschaft (TBG) and the Kreditanstalt für Wiederaufbau bank (KfW). In 1998, the TBG invested about $\$ 438$ million in high-technology startups. TBG is a subsidiary of the Deutschen Ausgleichsbank, a state-owned bank intended to finance medium-sized companies.

The government has spelled out several requirements that companies must meet to be eligible for government grants and subsidies: (1) Research-based companies are in the best position to receive funding. Sales operations will not receive funding, and clinical trials may receive some funding; (2) The German subsidiary/joint venture has to be assigned intellectual property; (3) The intent must be to create a long-term investment. Entities that are not intended to be stand-alone companies will not receive funding; (4) A well-conceived business plan is mandatory for financing; (5) There is no minimum on the number of jobs that have to be created; (6) The money raised in Germany has to be spent in Germany.

To be eligible for TBG funding, a company must have no more than 50 employees, must have less than $\$ 5.5$ million on its balance sheet, and must have a large company ownership less than $25 \%$.

\section{How much is available?}

Typical financing models are maximized at around $\$ 9$ million. Of this amount, about a third is a loan from the federal government. Another third is a loan from the state government, and is available only in selected states. The remaining third is equity made available from a venture capitalist and/or the US parent company. Different states have different programs, however, and the TBG funding is available independent of the company's location.

In addition to loan funding, research grants are available from the $\mathrm{BMBF}$ (Bundesministerium für Bildung, Forschung und Technologie) of up to $40-50 \%$ of the cost of a research project. Some states, notably Bavaria, provide additional research funds for eligible projects from the Bayerische Forschungsstiftung. For companies located in the former Eastern Germany, so-called GA grants are available to finance up to $43 \%$ of capital equipment needed for R\&D or manufacturing facilities. GA funding is unlimited- 
chemical companies, for example, have received billions of dollars for certain large projects (see Table 1).

\section{Additional opportunities}

Before an IPO, biotechnology companies can get mezzanine financing up to $\$ 5.5$ million from TBG as an equity investment. This TBG vehicle will dilute the company, but the capital is typically "cheaper" than funds offered by other mezzanine sources.

The new German (East Germany) states probably offer the most "bang for the buck" by making additional financing opportunities available. For example, a fund of the KfW called Beteiligungsfond Ost may invest up to $\$ 5.5$ million into a company. In addition, the KfW will cover $50 \%$ of the risk, leaving the investor to assume the rest.

For companies needing only smaller amounts of money, the East offers the highest multiples. If an investor puts $\$ 300,000$ of seed capital into a biotech startup, that company is then able to get another $\$ 2$ million by working with an approved bank. This money can then be used as the "equity portion" needed for a BMBF grant, increasing the capital to a maximum of $\$ 3.5$ million, effectively creating a funding multiple of 10 . This package, how-

Table 1. The maximum funding amounts of the subsidized federal and state loans.

Equity (US parent/VC)

TBG (subsidized loans up to)

State loan (varies from state to state)

Additional funding

Federal R\&D grants (no absolute limit; "doable" amount 4.5 million KfW(loan): mutually exclusive with TBG GA loans; up to $43 \%$ of capital investment in former 3 million ast Germany (no limit; amount is picked at random)

ever, excludes a company from receiving a possibly larger TBG funding package.

\section{How easy is it to get?}

Generally speaking, companies need a good story and experienced people to be eligible for financing. Having a scientific supporter in Germany, such as a well-regarded professor, does not hurt either. Companies who have or are close to running out of money in the US and are looking at German financing as a last resort will probably be disappointed.

Financing models in which a US venture capitalist or the US parent company itself brings in up to $\$ 3$ million are the easiest and quickest deals to close. They show commitment from the parent and eliminate the step of raising venture capital from German ven- ture capitalists. Many German venture groups have been reluctant to invest in a company that is majority-owned by a non-local company, fearing loss of any control over key decision-making processes.

If the US parent assigns only intellectual property and no cash, equity may be raised in Germany. The more likely financiers for such deals are venture funds owned by local banks, which have the mandate to create jobs in exchange for top rates of return. This process typically takes longer than deals in which the US parent invests intellectual property and cash.

The financing models depend largely on the location of the company in Germany. Federal funds are available anywhere, but the state programs vary. The most transparent models are in Berlin, Munich, and Cologne/Düsseldorf. In those places, deals have actually been completed or are close to being completed, so there is a track record. In summary, Germany does offer an opportunity for foreign biotechnology companies, with the caveat that the need for money needs to be accompanied by a strategic goal. Beyond that, CEOs who have succeeded at the endeavor advise their colleagues to be prepared for at least six to nine months of hard work. 